\title{
Bernard Mandeville on hypochondria and self-liking
}

\author{
MAURO SIMONAZZI \\ University of Camerino
}

\begin{abstract}
This article analyses how Mandeville's Treatise of the hypochodriack and hysterick passions (1711) was received in the medical environment, and I show that this work, in spite of being unusual and of a satirical nature, was seriously read and studied by eighteenth-century physicians. In the second part I will describe hypochondria as it is intended in the Treatise, with particular attention to talking therapy. In the third part I will show that in the Fable of the bees and in the Enquiry into the origin of honour hypochondria is associated with a frustration of the desire to be esteemed, and that in light of the theory of self-liking expressed in the Fable, it is possible to account for talking therapy's effectiveness as theorised in the Treatise.
\end{abstract}

Keywords: Mandeville, hypochondria, melancholy, talking cure, selfliking, desire to be esteemed

\section{INTRODUCTION}

The central theme in Mandeville's works is the acknowledgment of the crucial role that self-liking plays in human matters. Self-liking is a natural passion "by which every Individual values itself above its real Worth" (Mandeville 1924b, 130). Yet, as human beings tend to be insecure about their true value, public image and social appreciation is of great importance to them. Self-liking is the psychological cause of the desire to be esteemed by other human beings. It is the desire for social recognition which allows Mandeville to explain human behaviour at different levels, from everyday social relationships to commercial exchanges, religion, and politics. This is captured in a significant passage in the Fable of the bees part II, whereupon Mandeville sums up the results of his studies on human nature: "the most superlative Wish, which a Man possess'd, and entirely fill'd with it can make, is, that he suggestions. I am grateful also to Andrea Branchi, Harro Maas, Johan Olsthoorn, and the two anonymous referees for their helpful comments. 
may be well thought of, applauded, and admired by the whole World, not only in the present, but all future Ages" (Mandeville 1924b, 64). Thus, if human behaviour can be explained by the desire for social recognition, what happens then when such need is not satisfied, or worse, when the interest itself in the opinion of others disappears?

Mandeville argues that when the desire to be esteemed fades the symptoms of hypochondria appear. In this article I show how those same symptoms that Mandeville himself described in his work on hypochondria and hysteria, Treatise of the hypochondriack and hysterick diseases, are found (at least implicitly) in both the Fable of the bees and in the Enquiry into the origin of honour.

However, before addressing the central point of this article I will dedicate a few pages to discuss the reception that the Treatise received in eighteenth-century Britain. This is important not only because of the lack of studies on this subject, but because this research will show that, in spite of his satirical style, Mandeville was taken seriously by the physicians of his time. I will then move on to examine in detail the Treatise, which is very interesting for three reasons: firstly, hypochondria is approached from a point of view that is not strictly medical, but takes into account psychological and existential elements; secondly, great importance is attributed to the relationship between physician and patient; finally, a kind of talking cure is theorised. I proceed to argue that in the Fable a moral conception of hypochondria is present, according to which hypochondria is caused by the absence of self-liking. From this perspective, the relationship of trust between doctor and patient, coupled with talking therapy, would re-establish the patient's interest in the "opinion of others". The comparison between hypochondriac symptoms as described in the Treatise and the effects of weakened self-liking as described in the Fable constitutes the main evidence for my thesis.

\section{MANDEVILLE AND THE DIFfUSION OF THE TREATISE OF THE HYPOCHONDRIACK AND HYSTERICK DISEASES}

Until recently, the Treatise of the hypochondriack and hysterick diseases was one of the least known of Mandeville's works. However, there has been a change of trend, as indicated by new translations of the Treatise into Italian (Mandeville 2009) and French (Mandeville 2012), and by the appearance of several articles on the text, as well as an entire volume 
dedicated to the conception of hypochondria in Mandeville. ${ }^{1}$ The increasing interest in the Treatise is justified for at least two reasons: first, a talking cure is now considered to be fundamental in psychology and psychiatry, rendering Mandeville's Treatise an interesting historical document. Second, increasing attention has been paid to Mandeville's medical training and to the influence that his studies on hypochondria may have had on the development of his theory of the passions. Such a theory was gradually put together over the twenty-year span, from the first edition of the Fable of the bees in 1714 to the publication of the Enquiry into the origin of honour in 1732.

The Treatise was first published in 1711, six years after Mandeville had written the apologue The grumbling hive. It was then reprinted in 1715 , shortly after the publication of the first edition of the Fable. ${ }^{2}$ In 1730 Mandeville published a proper second edition, expanded in length by about a third and with a slightly changed title. ${ }^{3}$ At that time Mandeville had just given to the press the Fable II and was presumably busy writing the Enquiry into the origin of honour.

Apparently the Treatise was quite well received, perhaps exceeding expectations, judging by the fact that the publisher issued a second print only a few months after the first. Besides, while in the first edition the frontispiece contains Mandeville's personal address, in the reprint he decided to omit it, replacing it with a few lines inviting whoever was interested in starting therapy to get in touch with him through the bookseller or the publisher. This little amendment suggests that Mandeville might have been annoyed by readers soliciting his help.

Since there are no studies on the diffusion of the Treatise in the eighteenth century, it is difficult to say at this stage if and how Mandeville's theories were discussed by his contemporaries. Some brief observations attest that the Treatise circulated among English, Scottish, and Irish physicians.

\footnotetext{
${ }^{1}$ See Leigh (1961, 23-28); Veith (1965, 153-154); Rousseau (1975, 11-21); Shoenberg (1976); Carrive (1980, 71-96); Jackson (1986, 287-289); Collins (1988); McKee (1991); McKee (1995); Cook (1999); de Marchi (2001); Branchi (2004, 24-40); Simonazzi (2004, 293-411); Schmidt (2007, 150-162); Simonazzi (2008, 97-151); Hilton (2010); KleimanLafon (2013).

${ }^{2}$ The Fable of the Bees was published for the first time in 1714 in the form of a comment to the apologue The grumbling hive (1705), and was subsequently expanded in the 1723 edition and in the final one of 1724. In December 1728 (on the frontispiece the date 1729 appears) Mandeville gave to press the Second Part of the Fable in the form of a dialogue.

${ }^{3}$ Mandeville substitutes the term "passions" with "diseases".
} 
Mandeville's name appeared for the first time in a medical work within the Observations in physick, both rational and practical, written by Thomas Apperley, in 1731. Apperley, who was a fellow of St. John's College, Cambridge, quotes Mandeville in support of his thesis on the function of menstruum in the digestive process (Apperley 1731, 183184). The Treatise was later quoted as an authoritative source on food properties, in particular on fish, by physician Thomas Withers (Withers 1777, 115-116). In 1782, William Black quotes Mandeville three times in his An historical sketch of medicine and surgery (Black 1782, 163, 220, 276). Mandeville's name is associated with that of Dr Robert Pitt (16531712), author of Crafts or the frauds, where he blows the whistle on the business agreement between doctors and chemists, all to the detriment of the patients. In the final pages of his book, Black lists the most important works on various symptoms, and the Treatise is quoted next to Cheyne's work. Two years later, Mandeville's name appears as an authoritative source on diet in the London Society of Physicians (A Society of Physicians in London 1784, 6: 119-120). In 1786 The Yorkshire magazine quotes Mandeville as the source of the principle according to which "if you like it, it's good for you", which was supposed to demonstrate the existence of a self-regulatory mechanism within the human body (The Yorkshire magazine 1786, 1: 50-51). If we look at dictionaries and encyclopaedias, we see that the entry "Mandeville" appears in A new biographical dictionary (Jones 1796, 293), and three years later it is included in Biographia medica as well (Hutchinson 1799, 2: 115-122). Even in Ireland the Treatise must have had a certain resonance, as demonstrated by the fact that the name of Mandeville appears in Pharmacomastix by Charles Lucas, published in Dublin in 1741. Lucas denounces the corruption of chemists in the sale of medicines, and the risk that medicines themselves may be adulterated. He repeatedly quotes Mandeville in support of the danger constituted by chemists (Lucas 1741, 38-39).

Nonetheless, it is in Scotland, at the Edinburgh Medicine Faculty, that Mandeville's medical work received acclaim. Mandeville's fortune in Scotland was probably due to Robert Whytt, King George III's physician (starting in 1761) and president of the Royal College of Physicians of Edinburgh. Whytt began his studies in Edinburgh, but subsequently attended Paris and Leyden universities. In 1765 Whytt published a work on hypochondria in which he quotes Mandeville among the authors who identified digestion as one of the causes of hypochondria and hysteria 
(Whytt 1765, 109). The list of these authors includes the most important physicians of the previous century, such as Highmore, Willis, Ettmüller, Sydenham, Boerhaave and Cheyne.

The Treatise appears in Edinburgh University Library (Catalogus librorum 1798, 234), but only in its first 1711 edition, the same quoted by Whytt. In the timespan from 1766 (the year immediately after the publication of the Observations) to 1795, at least three students specialising in nervous diseases quoted Mandeville in their academic dissertations: Jacobus Boswel in 1766 (the year following the publication of Whytt's work); Joannes Cowling in 1768, whose supervisor was William Robertson; and Joannes Haxby, in 1795, whose supervisor was George Baird. The Treatise frequently appears in medical libraries and in eighteenth century booksellers' catalogues too. In 1798 Sir Alexander Crichton, a Scottish physician well-known for having described what is now called "attention deficit hyperactivity disorders", quotes Mandeville to describe the digestive symptoms caused by hypochondria (Crichton 1798, 194).

In conclusion, this first reconstruction of the Treatise's reception in the eighteenth century demonstrates that Mandeville was taken seriously not only as a philosopher and author of the Fable of the bees, but also as a physician specialising in hysterical and hypochondriac diseases. The Treatise appears to have sparked interest, above all, through its study of the relationship between hypochondria and digestion, the importance of diet, its censure of chemists, and its attack on drug abuse. There are no references to the talking cure or to a moral etiology of hypochondria. The analysis of the Treatise's reception does not supply significant elements to relate the Treatise and the Fable. On the contrary: the two works were usually regarded separately. Mandeville himself did not mention the Fable in the Treatise nor the Treatise in the Fable. However, it is my contention that a point of contact exists between the two works: the theory of human passions. The Treatise, for example, not only analyses the hypochondriacs' passions, but also the physicians' passions (in particular "pride") by a method of analysis developed in the Fable. And in the Fable, Mandeville uses his medical and psychological skills to explain the symptoms of shame and, above all, to advance a theory of the causes of suicide. 


\section{HYPOCHONDRIA AND TALKING CURE}

What does Mandeville mean when he talks about hypochondria? Mandeville never says what hypochondria exactly is. In a way, the whole Treatise can be read as an attempt to find a definition for hypochondria through the description of its symptoms and the identification of its causes (Rousseau 1975, 14-15). Such an attempt, however, is destined to fail for at least three reasons. Firstly, because it is not a disease like any other, but a psychosomatic one, the causes of which are both of a physical nature (such as a digestion problem and indulgence in sexual pleasures) and of a psychological nature (such as fear of poverty and excessive study) (Mandeville 1981, 5-7). Secondly, a specific symptomatology does not exist, and so all cases are different from each other. Finally, because there is a very fine line between a simple, nonpathological melancholy disposition of the individual, as defined by Robert Burton in his The anatomy of melancholy, and a true melancholy habit, that is a proper pathology.

The Treatise is written in the form of a dialogue, spread through three days, between a physician called Philopirio, who represents Mandeville himself (Mandeville 1976, xi), and a hypochondriac patient, named Misomedon, and his wife, Polytheca, suffering from hysteria. A fourth character is their daughter, also affected by hysteria, who never appears on the scene. ${ }^{4}$ The dialogue form was not an original choice for a medical work, it was nonetheless an original decision to address the patients rather than his medical colleagues: "I conceiv'd it would be less Presumption, if I writ by way of Information to Patients, that might labour under them, than if I pretended to teach other Practitioners, that profess to cure them as well as my self" (Mandeville 1981, ix-x). This choice allows Mandeville "to deviate from the usual Method, and make what I had to say as palatable as I could to those, I had in view for my Readers" (Mandeville 1981, x-xi).

His method consists of making the patient tell his own life story. The importance of telling the disease history had been theorised before by Thomas Sydenham (1624-1689), who had taken inspiration from Bacon's reflections on the importance of classification and natural history. This method was supposed to be applicable to any kind of disease. It consisted of following the evolution of the various cases, comparing them, and identifying their common elements, so as to

\footnotetext{
${ }^{4}$ Hysteria is simply the name given by Mandeville to hypochondria when it affects women.
} 
distinguish what was peculiar to the patient from what was specific to the disease: "The whole philosophy of medicine consists in working out the histories of diseases, and applying the remedies which may dispel them; and Experience is the sole guide" (Sydenham 1696, 518). Mandeville follows in Sydenham's footsteps who, together with the physician Giorgio Baglivi (1668-1707), is quoted in the Treatise as one of his medical references. Sydenham's narrative of the disease history differs from that of the Dutch physician in many ways. First of all, the hypochondriac patient in the Treatise tells a life story, more than a story of disease. It takes into consideration events such as his father's death, his economic and social condition, occupation, relationship with family and friends, readings, travels, and amusements. As a second instance, Mandeville does not try to identify patterns or to formulate classifications. His interest in the patient is holistic, taking into consideration her history and specific individuality, not her disease, nor her medical history and classification of clinical case: "It is unreasonable to think, that from so general a Rule, sick People, and the several differences between one sick Person and another, or the same Person when sick of different Distempers, should be the only Exception" (Mandeville 1981, 79). Mandeville stresses the importance of psychological factors when building a rapport with the patient: "more especially those, in which the Fancy has so great a Share" (Mandeville 1981, 377). He also emphasizes that the patient must play an active role in therapy (Mandeville 1981, 380).

Therapy, as exposed in the Third Dialogue, does not include the use of drugs. It only requires exercise, healthy food, and a sound relationship between physician and patient, which is predicated on listening and talking:

If your Medicines do me no Good, I am sure your Company will [...]. You can't imagine, how a pertinent lively Discourse, or any thing that is sprightly, revives my Spirits. I don't know what it is that make me so, whether it be our talking together, the Serenity of the Air, or both; but I enjoy abundance of Pleasure, and this Moment, methinks, I am as well as ever I was in my Life (Mandeville 1981, 45-46).

Paulette Carrive maintained that by choosing the dialogue form, Mandeville meant to appear like "a man in conversation with his patient, in which patient and physician engage in a discussion about the illness as an issue of mutual concern, but at the same time separate from 
both" (Carrive 1980, 78-79). Francis McKee, instead, remarked that "by dramatizing the medical discourse, Mandeville attempts to produce a cathartic effect on the reader and patient. The dialogues 'divert' and 'entertain', thus combating hypochondria at some degree” (McKee 1995, 226). Surely, the form of a dialogue allows Mandeville to reach three goals: 1) to provide a vivid picture of hypochondria symptoms; 2) to show the subjective perception of the illness; 3) to show the therapy at work.

However, the Treatise leaves much to be desired regarding the etiology of its therapy, which is to say, it does not disclose what talking therapy is exactly, nor how it works.

\section{Talking therapy}

Mandeville's most direct source is probably Giorgio Baglivi, whose work underscores the importance of imagination and emphasized that selfsuggestion worsened the illness (Baglivi 1843, 211). Furthermore, he insisted that violent therapies be avoided and urged against the use of pharmacological treatment without joint psychological therapy; this promoted the tranquility and serenity of the patient (Baglivi 1843, 213214).

In the Treatise (1711) frontispiece, Mandeville promises to his readers to reveal "a Method intirely new" to treat hypochondria. However, upon opening the book the reader would have noticed that Mandeville dedicates much space to criticize traditional therapies, while the "Method intirely new" is shown, rather than explained or theorised. The Treatise is really the presentation of a theory in progress. Only in its last pages does Mandeville really clarify his new method. The patient Misomedon, voicing the reader's curiosity and bewilderment, asks Mandeville directly: "Then what is your Secret in the Cure of this difficult Distemper?" (Mandeville 1981, 343). Mandeville replies: "I allow my self time to hear and weigh the Complaints of my Patients" (Mandeville 1981, 343). Misomedon is surprised and disappointed (as Mandeville imagines all his readers will be): "But I meant Medicines, when I spoke of Secrets" (Mandeville 1981, 344). Philopirio replies that, as to the medicines, he has no secrets. He answers Misomedon this way:

\footnotetext{
${ }^{5}$ My translation from the original in French: "un homme conversant avec son malade, malade et médecin discutant ensemble de la maladie comme d'une chose qui à la fois les concerne tous deux et qui cependant leur est extérieure."
} 
"Then I must answer you, that [...] I have no Nostrums that I intend either to magnify or conceal" (Mandeville 1981, 344).

Only by radically changing the outlook is it possible to detect the method's novelty. At the end of the Treatise, Mandeville reveals his secrets to his readers. The rules to follow are three. First, to let patients speak, and not to prescribe them useless medicines. The second is a condition of the first: the physician must be ready to listen to his patient carefully, putting himself into the other's shoes, understanding his idiosyncrasies, getting to know his food aversions and exercise habits and preferences. In short, the physician must use his deep knowledge of the patient to tell which features are only part of human nature and which ones are due to the illness (Mandeville 1981, 344).

Talking therapy implies that the patient must play an active role and gain an understanding of the causes of his own illness. Such understanding is part and parcel with the therapy itself, even though Mandeville himself cannot explain the reason:

I am glad, that at last you are happily enter'd into a Sentiment of things which Words cannot express; and now I hope, looking back on the Passages of your Life, you'll easily find out your self the Procatartick Causes of your Distemper (Mandeville 1981, 208).

\section{Physiological and psychological causes of hypochondria}

Throughout the Treatise Mandeville criticises speculative physiciansi.e., those doctors who ignore experience and let themselves be carried away by "Flights of Invention in Physick" (Mandeville 1981, 95). The Dutch philosopher maintains that it is necessary to adhere to the most rigorous observation. However, epistemological scepticism and the empirical method are incompatible with the passionate structure of human nature. As Misomedon observes:

What I was going to tell you is, that, tho' I am convinced from what you have said, that Reasoning about Causes is not to be depended upon, [...] yet I find it is impossible to do without. There is a Gap between the Observations made on the Symptoms of a Disease, and what Experience teaches us about the Cure of it: I want to have that Gap fill'd up (Mandeville 1981, 230).

Upon Misomedon's explicit request the physician Philopirio hypothesises about the cause of hypochondria. Mandeville states that the immediate cause of hypochondria is a digestion defect due to the lack of those animal spirits that constitute a fundamental component of 
the menstruum, or ferment, through which foods are turned into chyle and therefore absorbed by the body via an action of blood. The problem is, therefore, to identify the cause of the excessive consumption of animal spirits:

the immoderate Exercise of the Brain, and Excess of Venery, are so generally the Occasion of the Hypochondriack Passions, that in all my Experience I have hardly met with any, where I had not Reason to impute the Distemper, in Part at least, to one or other of these, if not both: I speak of Patients, in whom the Malady has been confirm'd. It was then the Waste of Spirits, that robbing the Stomachick Ferment of what was required for its Volatilization, occasion'd those fix'd acid Salts that gave you the Heart-burning which was your first Complaint (Mandeville 1981, 212-213).

The waste of animal spirits may be due to a multiplicity of causes, from excessive study and sexual activity to "the least Emotion of my Mind" (Mandeville 1981, 215). Mandeville pays particular attention to the relationship between socio-economic status and hypochondria. He claims that wealth is a predisposing factor because, on the one hand, it urges the fear of losing one's belongings and, on the other hand, it stimulates passions and desires that are difficult to satisfy. Fear and dissatisfaction are psychological causes of the loss of animal spirits:

Immoderate Grief, Cares, Troubles and Disappointments are likewise often Concomitant Causes of this Disease; but most commonly in such, as either by Estate, Benefices, or Employments have a sufficient Revenue to make themselves easie: Men that are already provided for, or else have a Livelyhood by their Callings amply secured, are never exempt from Sollicitudes, and the keeping not only of Riches, but even moderate Possessions, is always attended with Care. Those that enjoy 'em are more at leisure to reflect, besides that their Wishes and Desires being larger, themselves are more likely to be offended at a great many Passages of Life, than People of lower Fortunes, who have seldom higher Ends, than what they are continually employed about, the getting of their daily Bread (Mandeville 1981, 219-220).

In this way, hypochondria is connected to passions, wishes, expectations, social condition, desire for social advancement, fear of failure, and self-realization. It is a psychosomatic disease because the psychological dimension acts on the animal spirits, which are involved in digestion and can disturb the stomach. Mandeville, therefore, puts 
mind and stomach in strict relation through the mediation of animal spirits.

\section{HYPOCHONDRIA AND SELF-LIKING}

This section argues that if we want to find a psychological hypothesis regarding the causes of hypochondria we must set aside the Treatise, and focus our attention on the theory of passions developed in the Fable II and in the Enquiry. A psychological or moral etiology of melancholy can already be found in the works of some philosophers such as Michel de Montaigne, Robert Burton, and Thomas Hobbes. Hobbes, in particular, stated in Leviathan (1651) that mental health is a matter of balancing the dominant passion, since mental illness is caused by excessive strength or weakness of the desire for power. Excessive selfesteem (i.e., vain-glory or pride) is the cause of madness, while an excessive insecurity results in dejection of mind: "The Passion, whose violence, or continuance, maketh Madnesse, is either great vaine-Glory; which is commonly called Pride, and selfe-conceipt; or great Dejection of mind" (Hobbes 2012, 112).

In the beginnings of his career, Mandeville's interest was mainly of a medical nature, but after 1711 the Dutch philosopher probably neglected the study of medicine (as stated in the Preface to the edition of the Treatise in 1730) and dedicated himself to developing his theory of the passions (Mandeville 1981, xxii). In particular, his attention was concentrated on the passion of self-liking. In the Preface to Fable II, Mandeville describes himself (alias Cleomenes) as a man who, after a medical education, dedicated himself to philosophy (Mandeville 1924b, 16). In the second dialogue he reveals an important insight into human nature: the importance of other people's opinions and the desire to be esteemed (Mandeville 1924b, 64). Mandeville's emphasis on self-liking is the result of twenty years of reflection, and runs parallel to his studies on hypochondria. We may say that in the Treatise Mandeville analyses the pathology of passions, whereas in the Fable and in the Enquiry he tries to outline their physiology. This research develops gradually, and it is only in the Third Dialogue of the Fable II, that is seventeenth years after the publication of the Treatise' first edition (and a few months before the second edition was issued), that Mandeville introduces the concept of self-liking for the first time (Mandeville 1924b, 131). Then, it is in the Enquiry into the origin of honour, published in 1732 (two years after the publication of the Treatise' second edition) that the Dutch 
physician completes his theory, modifying along the way the views expressed in Fable I. ${ }^{6}$ In the Enquiry he makes a distinction between selfliking (self-esteem), self-love (self-conservation instinct) and pride (a vice deriving from an excess of self-liking):

Hor: I now understand perfectly well what you mean by Self-liking. You are of Opinion, that we are all born with a Passion manifestly distinct from Self-love; that, when it is moderate and well regulated, excites in us the Love of Praise, and a Desire to be applauded and thought well of by others, and stirs us up to good Actions: but that the same Passion, when it is excessive, or ill turn'd, whatever it excites in our Selves, gives Offence to others, renders us odious, and is call'd Pride. As there is no Word or Expression that comprehends all the different Effects of this same Cause, this Passion, you have made one, viz. Self-liking, by which you mean the Passion in general, the whole Extent of it, whether it produces laudable Actions, and gains us Applause, or such as we are blamed for and draw upon us the ill Will of others.

Cleo. You are extremely right; this was my Design in coining the Word Self-liking (Mandeville 1971, 6-7).

Self-liking should not be confused with the desire for social recognition: they are inseparable, but they are not the same thing. In fact, self-liking is "that great Value, which all Individuals set upon their own Persons; that high Esteem, which I take all Men to be born with for themselves" (Mandeville 1971, 3). Love of praise or desire for applause is only the effect of self-liking (Mandeville 1971, 5). The desire for social recognition is so important because self-liking...

seems to be accompany'd with a Diffidence, arising from a Consciousness, or at least an Apprehension that we do over-value ourselves: It is this that makes us so fond of the Approbation, Liking and Assent of others, because they strengthen and confirm us in the good Opinion we have of ourselves (Mandeville 1924b, 130).

Mandeville explicitly states that a good balance of the passion of self-liking is the necessary ingredient for good mental health. It is significant, in my opinion, that Mandeville himself shows a certain kind of reluctance in linking self-liking with health and psychological illness, almost as if he found it difficult to reconcile the Treatise with the Fable:

\footnotetext{
${ }^{6}$ In Fable I Mandeville affirmed that pride and shame were two separate passions; in the Enquiry, instead, he states that they are both symptoms of self-liking (Mandeville 1971, 12).
} 
Hor: Self-love I can plainly see induces him to labour for his Maintenance and Safety, and makes him fond of every thing which he imagines to tend to his Preservation: But what good does the Selfliking to him?

Cleo: If I should tell you, that the inward Pleasure and Satisfaction a Man receives from the Gratification of that Passion, is a Cordial that contributes to his Health, you would laugh at me, and think it far fetch'd (Mandeville 1924b, 134).

In this regard, it is the passage where Cleomenes fears ridicule that Mandeville indicates the introduction of a new and counterintuitive concept. The desire to be esteemed is a fundamental element for psychological health. Mandeville doesn't explicitly theorise that selfliking plays a role in hypochondriac symptoms. However, in the Fable of the bees there are a series of hints that attest to Mandeville's preoccupation with hypochondria while describing the effects of deficient self-liking; these effects range from depression to suicide. If we compare the hypochondriac symptoms described in the Treatise, for example, with the psychological symptoms linked to low self-esteem found in the Fable, not only do we notice an extraordinary similarity but (at least in one case) the use of the very same description.

In what follows, I will examine two key-passages of the Fable: the first relates to the symptoms of shame (one of the effects of self-liking); the second is the description of the psychological state of those who want to commit suicide (the most severe form of hypochondria).

Shame is the symptom of the wound of self-liking:

When a Man is overwhelm'd with Shame, he observes a Sinking of the Spirits; the Heart feels cold and condensed, and the Blood flies from it to the Circumference of the Body; the Face glows; the Neck and part of the Breast partake of the Fire: He is heavy as Lead; the Head is hung down; and the Eyes through a Mist of Confusion are fix'd on the Ground: No Injuries can move him; he is weary of his Being and heartily wishes he could make himself invisible: But when, gratifying his vanity he exults in his Pride, he discovers quite contrary Symptoms; his Spirits swell and fan the Arterial Blood; a more than ordinary Warmth strengthens and dilates the Heart; the Extremities are cool; he feels Light to himself, and imagines he could tread on Air; his Head is held up; his Eyes are roll'd about with Sprightliness; he rejoices at his Being, is prone to Anger, and would be glad that all the World could take Notice of him (Mandeville 1924a, 67-68; see also Mandeville 1971, 12-13). 
ThatWe can point out at least five elements. 1) Shame causes a loss of animal spirits ("a Sinking of the Spirits"), which is exactly the cause of digestive problems, leading to hypochondria. 2) One of the symptoms of shame is the wish to be invisible-i.e., the annihilation of self-liking. (By contrast, when one's degree of self-liking is high, then that person "would be glad that all the World could take Notice of him"). 3) Symptoms of shame are described in the Fable as a general heaviness of heart and head ("the Heart feels cold and condensed [...] He is heavy as Lead"). Symptoms of Hypochondria have the same characteristics in the Treatise: "Sometimes my Spirits are oppress'd of a sudden with an unaccountable Sadness, and I feel a great Weight at my Heart; at the height of this Anxiety I am often seiz'd with such a terrible Fits of Crying, as if I was to be dissolv'd in Tears, by which yet I am generally reliev'd" (Mandeville 1981, 267). 4) Mandeville uses the same expression to define the symptoms of hypochondria and to describe the symptoms of a man who is ashamed, that is who is wounded in his self-liking. In fact, in the Treatise, Misomedon describes his psychological symptoms in order of increasing intensity. The most severe one invites the outcry: "Such a lerna malorum and Syndrome of Evils made me weary of my Life" (Mandeville 1981, 27). In Fable I Mandeville writes: "He is weary of his Being”. 5) Even in those passages where Mandeville doesn't use the very same words, hypochondria's psychological symptoms are similar to those attributed in the Fable to patients who suffer from a lack of selfliking. Compare, for example, the suicide-passage from Fable II (analysed below) with the Treatise's description of the symptoms of hypochondria: "a vast enormous Monster, whose Savage force may in an Instant bear down my Reason, Judgment, and all their boasted Strength before it [...] I know it, I resist it, yet I can't overcome it" (Mandeville 1981, 53). It is a disease that "possess'd my Fancy for hours together, till the Horror of them entring deeper into my Soul, sometimes struck me with such unspeakable Pangs of Grief, as no Torture, or Death could ever be able to give the like" (Mandeville 1981, 49). The patient exclaims "How strange a thing in this Distemper of mine! To be so extraordinary well between whiles, as I am now, and sometimes to be plung'd into such an Abyss of Misery" (Mandeville 1981, 46).

In the Enquiry into the origin of honour Mandeville states that the Fable of the bees can be read as an attempt to describe the symptoms of self-liking: "The Author of the Fable of the Bees, I think pretends 
somewhere to set down the different Symptoms of Pride and Shame" (Mandeville 1971, 11).

This passage on the symptoms of shame is fundamental; in fact, Mandeville uses it twice (once in the Fable I and once in the Enquiry) to emphasize the essential function that self-liking plays in one's psychological health. In the Enquiry Mandeville emphasises the connection between shame and the extirpation of self-liking: "Sometimes Shame signifies the visible Disorders that are the Symptoms of this sorrowful Reflection on our own Unworthiness [...] all the Marks of Ignominy, that can be thought of, have a plain Tendency to mortify Pride; which, in other Words, is to disturb, take away and extirpate every Thought of Self-liking" (Mandeville 1971, 11).

Another crucial passage is the famous passage about suicide in Fable II, where Mandeville theorises that suicide is due to frustration of selfliking: vilified self-esteem may cause such suffering to overcome the natural resistance of self-preservation. Self-liking may become a cause of hatred against oneself:

Whilst Men are pleas'd, Self-liking has every Moment a considerable Share, tho' unknown, in procuring the Satisfaction they enjoy. It is so necessary to the Well-being of those that have been used to indulge it; that they can taste no Pleasure without it, and such is the deference, and the submissive Veneration they pay to it, that they are deaf to the loudest Calls of Nature, and will rebuke the strongest Appetites that should pretend to be gratify'd at the Expence of that Passion. [...] It [Self-liking] is the Mother of Hopes, and the End as well as the Foundation of our best Wishes: It is the strongest Armour against Despair, and as long as we can like any ways our Situation, [...] we take care of ourselves; and no Man can resolve upon Suicide, whilst Self-liking lasts: but as soon as that is over, all our Hopes are extinct, and we can form no Wishes but for the Dissolution of our Frame: till at last our Being becomes so intolerable to us, that Selflove prompts us to make an end of it, and seek Refuge in Death (Mandeville 1924b, 135-136).

Mandeville is here claiming that self-liking is necessary for psychological well-being: it is the source of hopes and wishes, the foundation of care of ourselves. If the psychological mechanism does not work properly (and, when this happens, we no longer seek the esteem of others) then "self-love prompts us to make an end of it, and seek Refuge in Death". 
Self-liking can turn into an apparent self-hatred, as pointed out by Horace: "You mean Self-hatred; for you have said your self, that a Creature cannot love what it dislikes" (Mandeville 1924b, 136). How can self-liking turns into self-hatred? Mandeville deems this impossible. He therefore claims, interestingly, that suicide is rather the last desperate act of kindness towards oneself: it puts to an end suffering that cannot otherwise be avoided: "whoever kills himself by Choice, must do it to avoid something, which he dreads more than that Death which he chuses. Therefore, how absurd soever a Person's Reasoning may be, there is in all Suicide a palpable Intention of Kindness to ones self" (Mandeville 1924b, 136).

The evidence mustered here suggests that the psychological cause of hypochondria is a shortage of self-liking, which, in turn, causes low selfesteem and the annihilation of the desire for approval and sociability. Hypochondria is the loss of self-liking, the lack of faith and interest in other people's esteem. Evidence of this becomes apparent if we contrast characteristics of self-liking with the symptoms of hypochondria: they are opposites. Self-liking is the principle of sociability, while hypochondria causes loneliness. Self-liking is the desire for other people's esteem, while hypochondria is the lack of interest in other people's judgment.

One main virtue of my interpretation is that it explains why talking therapy is so effective: it allows the patient to regain the lost sense of self-liking. The physician's role would be to delve into the complex psychological and passionate world of his patient, and to re-establish a dialogue that may give back faith and interest in himself and in his public image. The therapy, then, would consist of self-analysis and introspection: "In Distempers, where the Imagination is chiefly affected, Men, without any other Remedies, may often reason themselves into Health" (Mandeville 2001, 187).

The Treatise suggests that there is a correlation between stomach disorders, hypochondria, and talking therapy; but Mandeville doesn't explain how words can affect the stomach, even if he does try to identify the link between stomach and thought. It is worth noting that Mandeville's examples demonstrate the influence of thought on the stomach (bad thoughts interfere with appetite and favourite foods are more easily digested)-though not the reverse. The framework, opened by new considerations on self-liking dynamics, allows the reader to identify a link between the psychic and somatic dimensions of personal 
health. Stomach ailments can be seen as an effect of hypochondria, not as one of its causes. This resolves the Treatise's tensions: diminished self-liking is the cause of hypochondria, stomach disorders is one of the illness' symptoms, and the spoken word would play the role to retrieve the patient's lost sense of self-liking.

Let me reiterate my argument in brief: self-liking can cause either pride or shame. Pride or shame can manifest themselves physiologically. Excessive shame ruins the stomach because of "a sinking of spirits". Hypochondria thus has both psychological and physical pain. In practice, it makes one lonely and solitary. The cure is social interaction, but the patient does not want interaction because society has shamed him. The talking cure mimics interaction by reintroducing the regulative mechanism of social appreciation.

While there is textual evidence and we can track precedents among those who identify the cause of hypochondria in something similar to what Mandeville calls self-liking (pride, glory or desire for power), the etiological problem remains an open question, of which Mandeville himself reconsidered several times, highlighting the dangers of attempting to find medical explanations beyond what we can observe and experience: "Physicians, with the rest of Mankind, are wholly ignorant of the first Principles and constituent Parts of Things, in which all the Virtues and Properties of them consist" (Mandeville 1924b, 161162).

It is impossible, however, to explain through observation alone and without resorting to conjectures how and why words may influence the symbolic dimension and the passions, and in which way passions and ideas may interact with the body. It is possible to show that words have a therapeutic effect, as it is possible to detect the existence of a relation between symbolic and physic dimensions; nevertheless, according to Mandeville, to reach a better definition is a mission that goes beyond human capacities:

I am persuaded that our Thoughts, and the Affections of the Mind, have a more certain and more mechanical Influence upon several Parts of the Body, than has been hitherto, or in all human Probability, ever will be discovered (Mandeville 1924b, 162).

\section{CONCLUSION}

I started off by analysing the talking cure; this constitutes one of the most important aspects of the foregoing historiography. I then 
investigated the explanations that Mandeville provides for its effectiveness. Furthermore I have argued that the theory of the passions that the Dutch physician elaborated in the twenty years between the first edition of the Fable and the Enquiry may provide an answer to problems that remained unsolved in the Treatise (1711). In particular, I defended the thesis that within the Fable is a theory of hypochondria that is based on a lack of self-liking. To this end, I showed that when Mandeville describes the symptoms of a lack of self-liking he resorts to the very same description that he makes for the symptoms of hypochondria. One unsolved problem in the Treatise concerns the talking cure work-i.e., how does it work? Mandeville couldn't solve this from a medical perspective by investigating the pathology of the passions. However, his philosophical perspective provides a framework for investigating the passions via a theory of self-liking.

The elaboration of his theory of passions runs parallel to his studies on hypochondria, but self-liking appears for the first time only in Fable II in 1729. Mandeville was unable to fully realize his project of "anatomizing the invisible Part of Man" (Mandeville 1924a, 145), and to discover the fundamental role of the desire to be esteemed, in order to apply them to his research on the causes of hypochondria. The Dutch physician left us with a medical work, the Treatise, where he describes his particular therapeutic method based on talking therapy and trust between doctor and patient; he also left us with a philosophical thesis, found in the Fable and in the Enquiry into the origin of honour, in which we can find a theory of the passions that explains the reasons why such a therapy is effective.

\section{REFERENCES}

A Society of Physicians in London. 1784. Medical observations and inquiries, 6 vols. London: T. Cadell.

Apperley, Thomas. 1731. Observations in physick, both rational and practical. London: W. Innys and J. Leake.

Baglivi, Giorgio. 1843 [1704]. Opere complete medico-pratiche ed anatomiche. Florence: S. Coen.

Black, William. 1782. An historical sketch of medicine and surgery. London: J. Johnson. Boswel, Jacobus. 1766. Dissertatio medica inauguralis, de malo hysterico. Edinburgh: Typis Academicis.

Catalogus librorum ad rem medicam spectantium in bibliotheca academiae edinburgenae. 1798. Edinburgh: C. Stewart et socii. 
Cowling, Joannes. 1768. Dissertatio medica inauguralis, de hypochondriasi. Edinburgh: Balfour, Auld, et Smellie.

Branchi, Andrea. 2004. Introduzione a Mandeville. Rome: Laterza.

Carrive, Paulette. 1980. Bernard Mandeville. Passions, vices, vertus. Paris: Vrin.

Crichton, Alexander. 1798. An inquiry into the nature and origin of mental derangement. London: T. Cadell.

Collins, Rex Anthony. 1988. Private vices, public benefits: Dr Mandeville and the body politic. PhD thesis, University of Oxford.

Cook, Harold J. 1999. Bernard Mandeville and the therapy of "the clever politician". Journal of the History of Ideas, 60 (1): 101-124.

De Marchi, Neil. 2001. Exposure to strangers and superfluities. Mandeville's regimen for great wealth and foreign treasure. In Physicians and political economy: six studies of the work of doctor-economists, ed. Peter Groenewegen. London: Routledge, 67-92.

Haxby, Joannes. 1795. Disputatio medica inauguralis, de consuetudine. Edinburgh: Adamus Neill cum socii.

Hilton, Phillip. 2010. Bitter honey. Recuperating the medical and scientific context of Bernard Mandeville. Bern: Peter Lang.

Hobbes, Thomas. 2012 [1651]. Leviathan, vol. 2, The English and Latin texts (i), ed. Noel Malcolm. Oxford: Clarendon Press.

Hutchinson, Benjamin. 1799. Biographia medica, 2 vols. London: J. Johnson.

Jackson, Stanley W. 1986. Melancholia and depression. From Hippocratic times to modern times. New Haven: Yale University Press.

Jones, Stephen. 1796. A new biographical dictionary. London: J. Robinson, J. Wallis, J. Scatcherd, and E. Newbery.

Kleiman-Lafon, Sylvie. 2013. The healing power of words: medicine as literature in Bernard Mandeville's Treatise of the hypochondriack and hysterick diseases. In Medicine and narration in the XVIIIth century, ed. Sophie Vasset. Oxford: SVEC, 161-181.

Leigh, Denis. 1961. The historical development of British psychiatry. Oxford: Pergamon Press.

Lucas, Charles. 1741. Pharmacomastix: or, the office, use, and abuse of apothecaries explained. Dublin: S. Powell.

Mandeville, Bernard. 1924a [1724]. The fable of the bees, ed. F.B. Kaye, 2 vols. Oxford: Clarendon Press.

Mandeville, Bernard. 1924b [1729]. The fable of the bees. Part II, ed. F.B. Kaye, 2 vols. Oxford: Clarendon Press.

Mandeville, Bernard. 1971 [1732]. An enquiry into the origin of the honour, and the usefulness of Christianity in war, ed. Maurice M. Goldsmith. London: Frank Cass \& Co.

Mandeville, Bernard. 1976 [1711]. A treatise of the hypochondriack and hysterick passions. New York: Arno Press.

Mandeville, Bernard. 1981 [1730]. A treatise of the hypochondriack and hysterick diseases. In Collected works of Bernard Mandeville, ed. Bernhard Fabian and Irwin Primer, vol. 2. Hildesheim: Georg Holms Verlag.cc

Mandeville, Bernard. 2001 [1720]. Free thoughts on religion, the church \& national happiness, ed. Irwin Primer. New Brunswick: Transaction Publishers. 
Mandeville, Bernard. 2009. Trattato sulle malattie ipocondriache e isteriche, ed. by Domenico di Iasio, Lecce: Pensa Multimedia.

Mandeville, Bernard. 2012. Un traité sur les passions hypochondriaques et hysteriques, ed. Sylvie Kleiman-Lafon. Grenoble: Ellug.

McKee, Francis. 1991. An anatomy of power: the early works of Bernard Mandeville. Glasgow. Ph.D. thesis, University of Glasgow.

McKee, Francis. 1995. Honeyed words: Bernard Mandeville and medical discourse. In Medicine and enlightenment, ed. Roy Porter. Amsterdam: Rodopi, 223-254.

Rousseau, George S. 1975. Mandeville and Europe: medicine and philosophy. In Mandeville studies, ed. Irwin Primer. The Hague: M. Nijhoff, 11-21.

Schmidt, Jeremy. 2007. Melancholy and the care of the soul. Aldershot: Ashgate.

Shoenberg, P.J. 1976. A dialogue with Mandeville. The British Journal of Psychiatry, 129 (2): $120-124$.

Simonazzi, Mauro. 2004. La malattia inglese. La melanconia nella tradizione filosofica e medica dell'Inghilterra moderna. Bologna: Il Mulino.

Simonazzi, Mauro. 2008. Le favole della filosofia. Saggio su Bernard Mandeville. Milan: FrancoAngeli.

Sydenham, Thomas. 1696 [1676]. Observationes medicae. In The whole works of that excellent practical physician Dr Thomas Sydenham. London: R. Wellington.

The Yorkshire Magazine. 1786. 2 vols. York: T. Wilson.

Veith, Ilza. 1965. Hysteria. The history of a disease. Chicago: University of Chicago Press.

Whytt, Robert. 1765. Observations on the nature, causes, and cure of those disorders which have been commonly called nervous, hypochondriac, or hysteric. Edinburgh: J. Balfour.

Withers, Thomas. 1777. Observations on chronic weakness. York: A. Ward.

Mauro Simonazzi is researcher at the School of Law, University of Camerino. His research interests include the history of philosophy, the history of psychiatry and the history of political thought. He is the author of La malattia inglese. La melanconia nella tradizione filosofica $e$ medica dell'Inghilterra moderna (2004); Le favole della filosofia. Saggio su Bernard Mandeville (2008); Mandeville (2011); Degenerazionismo. Psichiatria, eugenetica e biopolitica (2013).

Contact e-mail: <mauro.simonazzi@unicam.it> 